\title{
The Influence of Additional Food Hotong Porridge with Moringa Leaves Mixture on Improvement Nutritional Status of Children Nutritional Children
}

\author{
Rahma Tunny ${ }^{1}$, Merryana Adriani ${ }^{2}$, Bambang Wirjatmadi ${ }^{2}$ \\ ${ }^{1}$ Master Student, ${ }^{2}$ Professor, Faculty of Public Health, Airlangga University
}

\begin{abstract}
Malnutrition is one of the main nutritional problems in Indonesia. Toddler is one of the age groups that are vulnerable to nutritional problems. One of the causes immediate nutritional problem is a lack of energy. This study aims to analyze the effect of supplementary feeding (PMT) hotong porridge mixed with moringa leaves and government biscuits on weight gain and underweight nutritional status in the working area of the Five Public Health Center. This study used Randomized Controlled Trial Design, with a quasi-experimental approach. The distribution of PMT hotong porridge with Moringa leaf mixture as a treatment group and the administration of PMT biscuits by the government program as a control group. The sample size was 32 toddlers. Data were analyzed using paired-sample T test. There was a significant effect on body weight and nutritional status after administration of PMT hotong porridge with moringa leaf mixture and PMT biscuits of government programs with p-value of 0.001 in the treatment group and the control group. Hotong slurry feeding and biscuit mix Moringa leaves government programs throughout a period of 30 days to take effect on the increase in body weight and nutritional status of children on the mark with most of the value of $\mathrm{z}$-score infants already stood at $-2 \mathrm{SD} \mathrm{s} / \mathrm{d}+2 \mathrm{SD}$, which means that most of the children under five are already in the nutritional status of the mall.
\end{abstract}

Keywords: Toddler, Weight, PMT, Nutritional status

\section{Introduction}

Malnutrition is a condition of body weight according to age (weight/age) not in accordance with the age that should be ${ }^{(1)}$. Malnutrition at the age of 2-5 years can affect mental development (ability to think). The brain reaches its maximum shape at the age of two years, malnutrition at this age can result in disruption of brain function permanently and malnutrition in general causes disruption in the processes of growth, energy production,body defense, structural behavior and function $^{(2)}$

Based on the results of Riskesdas, the prevalence of underweight by province and national is 2018 by $17.7 \%$

\footnotetext{
Corresponding author:

Merryana Adriani

E-mail: adrianimerryanafkmunair@gmail.com

Address: Kampus-C UNAIR, Mulyorejo,

Surabaya-Indonesia
}

including poor nutrition by $3.9 \%$ and under nutrition by $13.8 \%$. When compared with the national prevalence rate in $2007(18.4 \%)$, in $2010(17.9 \%)$ and in 2013 it was $19.6 \%$. Maluku Province is one of nine provinces with a high prevalence of severe under nutrition $(24.9 \%)^{(3)}$. In 2016 the incidence of malnutrition in Central Maluku district showed a figure of $5.1 \%$ in $2017(4.5 \%)$ and in $2018(4.5 \%)^{(4)}$

One direct cause of malnutrition is low nutrient intake $^{(1)}$. Nutrient intake can be obtained from macro nutrients such as energy, protein and fat needed in large quantities by the body and plays a role in providing energy $^{(2)}$. One ingredient food of high nutritional value, especially energy and protein is hotong. Hotong (Setaria Italica (L) Beauv) is a type of cereal crops sorghum. This plant is not widely known by the people of Indonesia and its processing is still limited.

Hotong plants grow widely in the Buru island area of Maluku and are used as staples with cassava,sago,corn, 
and rice. Hotong content high enough seed nutrients are carbohydrates $(84.02 \%)$, protein $(14.05 \%)$, fat $(3.3 \%)$, 100 grams of seeds contain energy hotong huge 359 calories $^{(5)}$. Moringa leaves also have a main source of several nutrients and theraupetic elements including antibiotics that stimulate the immune system. Moringa leaves have a high content of protein, vitamins and minerals that are good to be used as additional food for malnourished toddlers ${ }^{(6)}$.

\section{Method}

This research was a quasi experimental study with Randomized Control Trial Design. The sampling technique was simple random sampling. The sample were stunting as many as 32 people consisting of 16 infants in the treatment group and 16 infants in the control group with the inclusion criteria, namely children aged 24-59 months who suffered less nutrition with weight/ age. $z$-score $-3 \mathrm{SD}$ up to $<-2 \mathrm{SD}$, no disease, infants who are not breastfed and are willing to be respondents. This research was conducted for 30 days from 10 May to 10 June 2019 in the working area of the Public Health Center "Lima", Central Maluku. The independent variable was the administration of PMT hotong porridge mixed with moringa leaves and biscuits, the dependent variable was weight and nutritional status. PMT hotong porridge was given to the treatment group as much as 1 20 grams with $324 \mathrm{kcal}$ energy and 10 grams protein and biscuits PMT were given to the control group as much as 120 grams (12 pieces/day) with $300 \mathrm{kcal}$ energy and 8.45 grams protein.

Toddler characteristics in this study consisted of age and gender. Family characteristics include the number of family members and family income. Primary data were obtained from body weight measurements using digital scales with $0.01 \mathrm{~kg}$-accuracy, interviews with questionnaires and food recall form 1x24 hours. Secondary data were the number of malnourished children under the age of 24-59 months registered in the working area of the public health center "Lima".

The results of measuring under-fives weight use the weight/age index and compared with the z-score and are classified into 2 categories: malnutrition if included in the category of under nutrition and good nutrition and over nutrition if included in the category of good nutrition and over nutrition. Energy, protein and Fe intake compared with the cut of point Estimated Average Requirements (EAR), namely the deficit category if $<70 \%$ RDA, less if $70-80 \%$ RDA, while if $81-90 \%$ RDA and good category if $91-100 \%$ RDA .

To see the effect of energy, protein, and $\mathrm{Fe}$ intake on body weight and nutritional status of toddlers the pairedsample $\mathrm{T}$ test.

\section{Findings}

Characteristics of toddlers and families in table 1 shows that most of the toddlers in this study were aged 24-36 months in both the treatment group of 12 toddlers $(75 \%)$ and the control group of 11 toddlers $(68.75 \%)$. This age group is usually vulnerable to nutritional problems such as underweight, stunting and wasting. Toddlers aged 2 years have also entered the weaning period and have adopted the same diet with other families so that food intake is very important to support the growth process of infants ${ }^{(7)}$.

Table 1. Distribution of Toddler and Family Characteristics

\begin{tabular}{|l|l|l|l|l|}
\hline \multirow{2}{*}{ Characteristics } & \multicolumn{2}{l|}{ Treatment } & \multicolumn{2}{l|}{ Control } \\
\cline { 2 - 5 } & $\mathbf{n}$ & $\mathbf{0}$ & $\mathbf{n}$ & $\mathbf{3}$ \\
\hline \multirow{3}{*}{ Toddler Age (month) } & & & 11 & \\
$24-36$ & 12 & 75 & 2 & 12.5 \\
$37-48$ & 4 & 25 & 3 & 18.8 \\
$49-59$ & 0 & 0 & & 100 \\
\hline Total & & 100 & 16 & 100 \\
\hline
\end{tabular}


Cont... Table 1. Distribution of Toddler and Family Characteristics

\begin{tabular}{|l|l|l|l|l|}
\hline Toddler Sex & & & & \\
Male & 8 & 50 & 5 & 31.2 \\
Girl & 8 & 50 & 11 & 68.7 \\
\hline Total & 16 & 100 & 16 & 100 \\
\hline $\begin{array}{l}\text { Number of family members } \\
\text { Solid (>4 people) }\end{array}$ & 7 & & & \\
Rarely ( $\leq 4$ people) & 9 & 43.8 & 5 & 31.2 \\
\hline Total & 16 & 56.2 & 11 & 68.8 \\
\hline $\begin{array}{l}\text { Family Income } \\
<\text { UMK }\end{array}$ & 16 & 100 & 16 & 100 \\
$\geq$ UMK & 0 & 100 & & \\
\hline Total & 16 & 0 & 4 & 25 \\
\hline
\end{tabular}

The sex in this study were mostly women, both in the treatment group of 8 toddlers $(50 \%)$ and the control group of 11 toddlers (68.75\%). Research in Ghana states that girls are more at risk of nutritional problems compared to boys. That is because in parenting, diet and care, boys take precedence over girls ${ }^{(8)}$.

The number of family members in this study mostly had sparse family members ( $\leq 4$ people), namely in the treatment group of 9 toddlers $(56.25 \%)$ and the control group of 11 toddlers $(68.75 \%)$. This shows that the number of members in a family can influence the less optimal distribution and level of food consumption. Families with a large number of family members tend to get less food available. Lack of food availability in a long time can affect the low level of food consumption and have an impact on malnutrition ${ }^{(9)}$

The level of family income in the treatment group $(100 \%)$ and the control group $(75 \%)<\mathrm{UMR}$. Family income is one of the socio-economic indicators that play a role in providing food and family eating patterns. Low income can be one of the factors causing underweight nutritional status in infants, if the amount of income is low, then the level of food expenditure is also low so that it can cause low purchasing power and availability of food that contributes to the level of suboptimal nutritional consumption ${ }^{(\mathbf{1 0 )}}$.

Prior to PMT administration,most toddlers experience a deficit in food intake. In the treatment group namely 14 toddlers $(87.50 \%)$ deficits in energy intake, 5 toddlers $(31.25 \%)$ deficits in protein intake and 9 toddlers $(56.25 \%)$ had deficits in Fe intake.

The control group most of the toddlers experienced energy intake deficits namely 12 toddlers (75.0\%), 4 toddlers $(25.0 \%)$ had a protein intake deficit and 12 toddlers $(75.0 \%)$ had a deficit in Fe intake.

In the treatment group, the level of energy intake deficit was reduced to 2 toddlers $(12.50 \%)$, the level of protein and $\mathrm{Fe}$ intake decreased deficits so that there was no deficit intake of toddlers.

In the control group, there was a decrease in the deficit energy intake to 6 children under five $(37.50 \%)$. The majority experienced an increase in the level of protein intake, namely 6 toddlers $(37.50 \%)$ and $\mathrm{Fe}$ deficit intake increased to less intake, namely 9 children under five $(56.25 \%)$.

The test results differ in levels of energy, protein and Fe consumption between the treatment group and the control group after PMT administration with p-value $=0.007$. Previous research stated that there was a change in the level of energy consumption in the treatment and control groups after the administration of PMT by $\mathrm{p}=0.008^{(\mathbf{1 1})}$. This study is other states that people with a less risky energy consumption 6.73 malnutrition was comparable to the $\mathrm{n}$ that the energy consumption enough $^{(\mathbf{1 2})}$. 
The effects of energy,protein and Fe intake on body weight and nutritional status before and after PMT administration are presented in table 4 .

Table 2. Effects of Energy, Protein and Fe Intake on Body Weight and Nutritional Status Before and After Giving PMT

\begin{tabular}{|l|l|l|l|l|}
\hline \multirow{2}{*}{ Average } & \multicolumn{2}{l|}{ Treatment } & Control \\
\cline { 2 - 5 } & Before & After & Before & After \\
\hline Energy (\%) & 65.49 & 80.03 & 66.60 & 71.00 \\
\hline Protein (\%) & 79.53 & 95.88 & 85.27 & 86.61 \\
\hline Fe (\%) & 72.00 & 81.32 & 69.37 & 76.40 \\
\hline BW (kg) & 7.93 & 10.06 & 8.05 & 8.95 \\
\hline Z-Score & 2.58 & 3.86 & 2.02 & 2.93 \\
\hline
\end{tabular}

Table 2 showed that the treatment group or the control group increased intake of energy, protein and Fe. In the treatment group, the intake of energy, protein, $\mathrm{Fe}$, body weight and nutritional status increased after administration of hot porridge mixed with moringa leaf.

The results of different tests of energy intake,protein intake and Fe intake on body weight and nutritional status before and after PMT administration showed significant differences, namely in the treatment group $\mathrm{p}=0.001$ and the control group $\mathrm{p}=0.039$ and $\mathrm{p}=0.001$.

\section{Discussion}

\section{Effects of Moringa Leaf Hotong Slurry Supplement Supplementation for Weight Loss}

PMT hotong porridge with moringa leaf mixture is a snack made from several specific ingredients, as the main ingredient of hotong flour and Moringa flour with a comparison of certain nutritional levels in order to obtain high nutritional value. Consumption hotong flour and flour of Moringa is alternative way to promote weight loss nutritional status of stunting.

Hotong has several advantages compared with rice,nutrients are protein on hotong 3 times greater $(13.05 \mathrm{~g})$ of protein in rice $(5.0 \mathrm{~g})$, carbohydrates at hotong of $84.02 \mathrm{cal}$ and at $70-80 \mathrm{cal}$ rice and fat in hotong 3.37 grams greater than fat in rice that is $1.0-2.0 \mathrm{~g}^{(5)}$.

Moringa leaves also have several advantages including vitamin $\mathrm{C}$ in moringa is equivalent to 7 times vitamin $\mathrm{C}$ in citrus fruits, 4 times calcium in milk, 3 times potassium in bananas, 2 times protein in yogurt, 4 times vitamins in carrots and 25 times iron in $\operatorname{spinach}^{(6)}$.
Moringa leaves also contain 46 antioxidant compounds that protect the body against the damaging effects of free radicals by neutralizing them before they can cause cell damage and disease.

The results of the study are known before giving hotong porridge the mixture of Moringa leaves the average value of body weight is $7.93 \mathrm{~kg}$ and after administration of hotong porridge the mixture of Moringa leaves the average value of a toddler's body is $10.06 \mathrm{~kg}$, meaning that there is an increase in toddler body weight after the administration of hotong pulp mixed with moringa leaves in the treatment group was $2.13 \mathrm{~kg}(8.50 \%)$

Hotong porridge mixed with moringa leaves can be used as an alternative intake of morning uptake with complete nutritional content. by consuming 1 plate or 120 grams of hotong porridge mixed with moringa leaves can be fulfilled energy by $27.07 \%$ of RDA and protein $33.35 \%$ of RDA with the fulfillment of energy and protein intake in a day can increase weight gain in infants.

Earlier research stated that the more increased administration of Moringa leaves were added, the higher the content of protein,sugar,calcium,fiber content and $\beta$-carotene.This allows good absorption of nutrients contained in hotong and Moringa leaves ${ }^{(\mathbf{1 3})}$. Other studies also stated that the body weight of children who received average Moringa leaf powder was higher $(8.9 \pm 4.30 \mathrm{~g} /$ $\mathrm{kg}$ /day compared to $5.7 \pm 2.72 \mathrm{~g} / \mathrm{kg} /$ day in group II) and the level recovery is faster with an average stay time of $36 \pm 16.54 \mathrm{~g} / \mathrm{kg} /$ day compared to $57 \pm 19.20 \mathrm{~g} / \mathrm{kg} /$ day for those who do not receive Moringa supplements ${ }^{(14)}$. 
Other research states there is an effect of energy intake and protein intake on the addition of $\mathrm{BB}$ and $\mathrm{TB}$ under five after giving Moringa BMC PMT for 30days. The results of the analysis of energy intake and protein intake on $\mathrm{BB}$ and $\mathrm{TB}$ before and after giving $\mathrm{BMC}$ Moringa get the average value of $\mathrm{BB}$ before $10.29 \mathrm{~kg}$ and $\mathrm{BB}$ after $11 \mathrm{~kg}$. The average TB value before giving BMC Moringa PMT $88.12 \mathrm{~cm}$ and TB after an average of $89.16 \mathrm{~cm}^{(11)}$.

The results of the difference between body weight before and after PMT administration showed a significant difference with a value of $\mathrm{p}=0.001$.

\section{The Effect of Supplementation of Moringa Leaf Hotong Porridge Supplement Against Nutritional Status}

The results showed that the nutritional status of the treatment group prior to the administration of hotong porridge with Moringa leaf mixture was lacking nutritional status-the average nutritional status of children under five was $2.58 \mathrm{~kg}$ and after administration of hotong porridge with Moringa leaf mixture the average value of nutritional status was $3.86 \mathrm{~kg}$. meaning that an increase in nutritional status after the administration of hotong porridge mixed with Moringa leaves by $1.28 \mathrm{~kg}$

In the control group before administration of government program biscuits the average nutritional status was 2,02 whereas after administration of government program biscuits the average nutritional status was 2.93. This means that an increase in BB of 0,91 .

Statistical test results showed that there were significant differences before and after the administration of hotong porridge mixed with moringa leaves $(p=0.001)$ and government program biscuits with a value $(\mathrm{p}=0.001)$ on nutritional status. From the results of the study, samples that were given supplementary food both hot moringa mixed porridge with leaves and biscuits during the government program for 30days increased nutritional status, and the most effective improvement in nutritional status was supplementary feeding of hotong porridge mixed with moringa leaves.

Increasing the nutritional status of children under five is influenced by good food intake. Meeting the nutritional needs of children under five is the fulfillment of food intake that contains important compounds needed by the body of a toddler, including calories, protein, vitamins and minerals in accordance with their age. So at the age of five, balanced nutrition is needed so that the growth and development of toddlers can run well.

\section{Conclusion}

There is an effect of the administration of PMT hotong porridge with moringa leaf mixture and PMT biscuit of government programs to increase body weight and nutritional status of under-fives nutrition.

Suggestion is that the hotong porridge mixed with moringa leaves can be considered as an alternative for breakfast as a substitute for rice porridge,so as to reduce the incidence of malnutrition in infants.

Ethical Clearance: Taken from Ethical Commission of Health Research, No.125/HRECC.FODM/IV/2019, Faculty of Dentistry-UNAIR.

Source of Funding- Authors

\section{Conflict of Interest- No}

\section{References}

1. FKM-UI. Nutrition and Community Health. Jakarta: PT Raja Grafindo Persada; 2010.

2. Almatsier S. Basic Principles of Nutrition. Jakarta: Gramedia Pustaka Utama; 2005.

3. MoH-RI. Basic Health Research. 2018. Jakarta: MoH-RI; 2018.

4. Maluku Provincial Health Office. Data on the Number of Underweight Malnutrition. 2019.

5. Herodian S. Development of Buru Hotong (Setaria Italica (L) Beauv) as an Alternative Staple Food Source. 2011;(52). Available from: http://core/ ac.uk/download/pdf/32361799.pdf

6. Krisnadi A. Moringa Super Nutrition [Internet]. 2015. Available from: https://www.academia. edu/26227752/Kelor_Super_Nutrisi

7. Hapsari Sulistya. The Relationship of Energy and Protein Intake Level with the Occurrence of Malnutrition in Children 2-5 Years. 2013;2(April):25-30.

8. Ayensu Eunice, Darkwa Sarah. An Assessment of the Nutritional Status of under Five Children in Four Districts in the Central Region of Ghana. 2016. 
9. Adriani M, Wirjatmadi B. Toddler Nutrition and Health. Jakarta: Kencana Prenada Media Group; 2010.

10. Bharati S, Chakrabarty S, Som S, Pal M, Bharati P. Socio-economic Determinant of Underweight Children in West Bengal, India. Asian Pasific Journal of Tropical Medicine. 2004;571-581.

11. Juhartini. Effects of Biscuits and Moringa Mixed Food Additives on the Weight and Height of Malnutrition Toddler in the Work Area of the Kalumpang Health Center in Ternate City. 2015;2010(1):1-8.

12. Rahim FK. Journal of Public Health. 2014;9(2):11521.
13. Dachana KB. Effect of Dried Moringa (Moringa Oleifera Lam) Leaves On Rheological, Microstructural, Nutritional, Textural And Organoleptic Characteristics Of Cookies. 2013;4:991-7.

14. Urbain Zango, Steve L.Zoungrana, Aly Savadogo AT. Nutritional and Clinical Rehabilitation of Severely Malnourished Children with Moringa oleifera Lam. Leaf Powder in Ouagadougou (Burkina Faso) Urbain. 2013;4:991-7. Available from:https://www.scirp.org/journal/ PaperInformation.aspx?PaperID= 